\title{
NOKEN LITERATION: A WISDOM LOCAL IN IMPROVING INVESTMENT AWARENESS COMMUNITIES \\ Wike Juniati ${ }^{1}$ \\ 'Institut Agama Islam Negeri Fattahul Muluk Papua \\ Email: wikejuniati6@gmail.com (correspondence author)
}

\begin{abstract}
Noken literacy is a local wisdom program implemented by a literacy community in the land of Papua. This program was initiated with the aim of increasing the understanding of people in Papua about financial literacy. The method of implementation is by conducting field trips and direct assistance to the people involved in the economic activities of the market center in the Jayapura area. What distinguishes this program from other programs is because of the uniqueness of the objects carried by literacy activists when they go down to the field, namely a noken bag. Noken is one type of typical Papuan bag that has many philosophies about the Papuan people. It is hoped that the approach to using this unique bag of Papua will make people interested in understanding about financial literacy carried out by literacy activists. So that the decline of literacy and financial inclusion in the Sharia capital market in Papua can be overcome..
\end{abstract}

Keywords: Potential Islamic Financial System in Papua, Noken Literacy, Local Wisdom 


\section{Introduction}

Over the past few years, the development of the sharia economy globally has continued to experience fantastic growth. This is evidenced by the many countries that use the Islamic economic system. In Indonesia, the development of the Islamic financial system is growing rapidly from year to year in each sector. In the field of Islamic capital markets also have a record of encouraging developments. The data shows that the number of sharia shares (saham syariah) listed in the List of Sharia Securities (DES) and the Indonesian Sharia Stock Index (ISSI) are increasing every year.
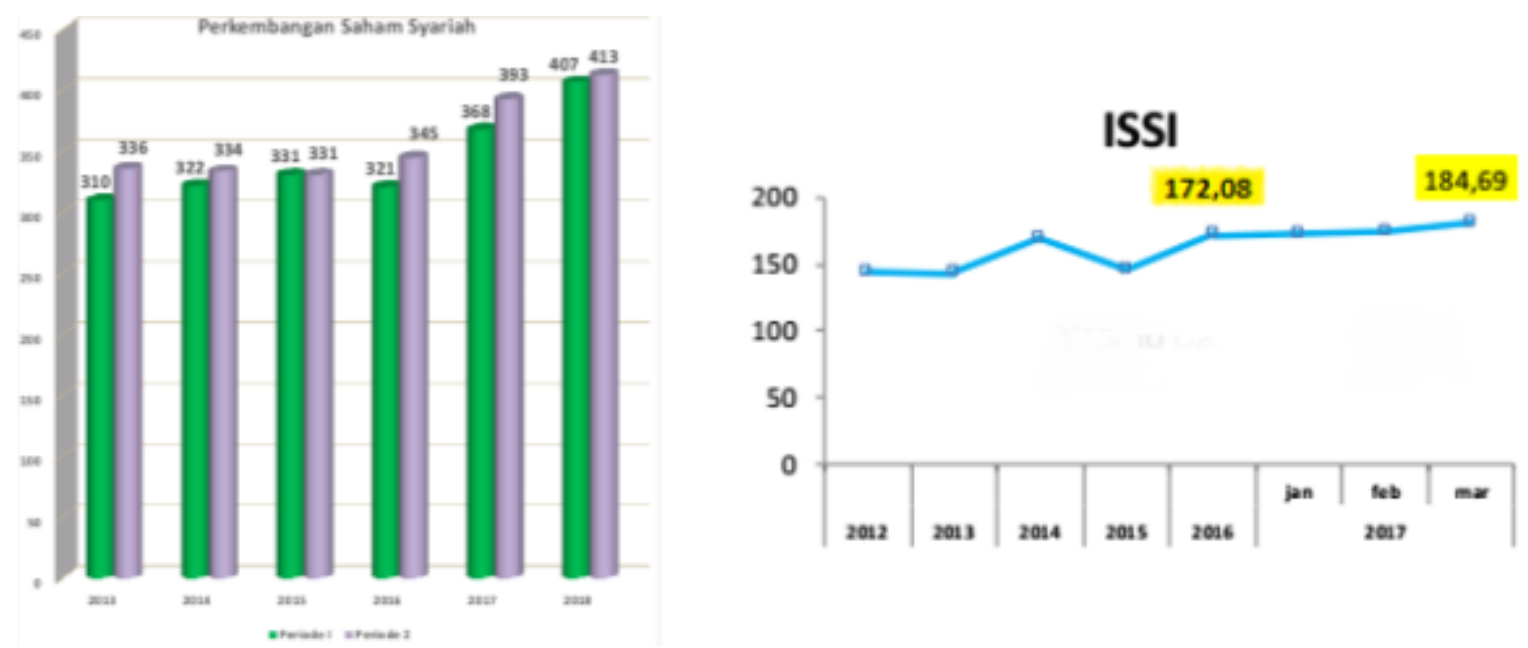

Source : Financial Services Authority(OJK)

However, the increase in the list of Islamic stocks and ISSI index was not followed by a significant increase in the number of domestic investors in the Indonesian capital market, especially the Islamic capital market. Where the number of Islamic capital market investors (shares) is still small when compared with the total population of Indonesia, which reaches 159,086 of the total population of Indonesia as much as \pm 267 million people (2018). In terms of demographics, the majority (92\%) of investors are concentrated in Java and Sumatra. This shows that the potential of the Islamic capital market in Indonesia is still very large and not evenly distributed. The main cause of the low number of Islamic capital market investors is inseparable from the lack of public knowledge and understanding of the Islamic capital market.(Financial Service Authority (OJK) 2019)

Based on a national survey conducted by the Financial Services Authority (OJK) in 2016 on financial literacy and inclusion, it was noted that the Islamic financial literacy and inclusion index was still very low compared to the conventional financial literacy and 
inclusion index. The data shows that the Islamic financial literacy index is $8.11 \%$ while conventional financial literacy is $59.74 \%$. This shows that the community's understanding of sharia finance is still low. Considering that Indonesia is an archipelagic country, it is fitting for each region to be carried out with equal socialization (OJK, 2019). The following data is the level of literacy and Islamic finance in various regions:

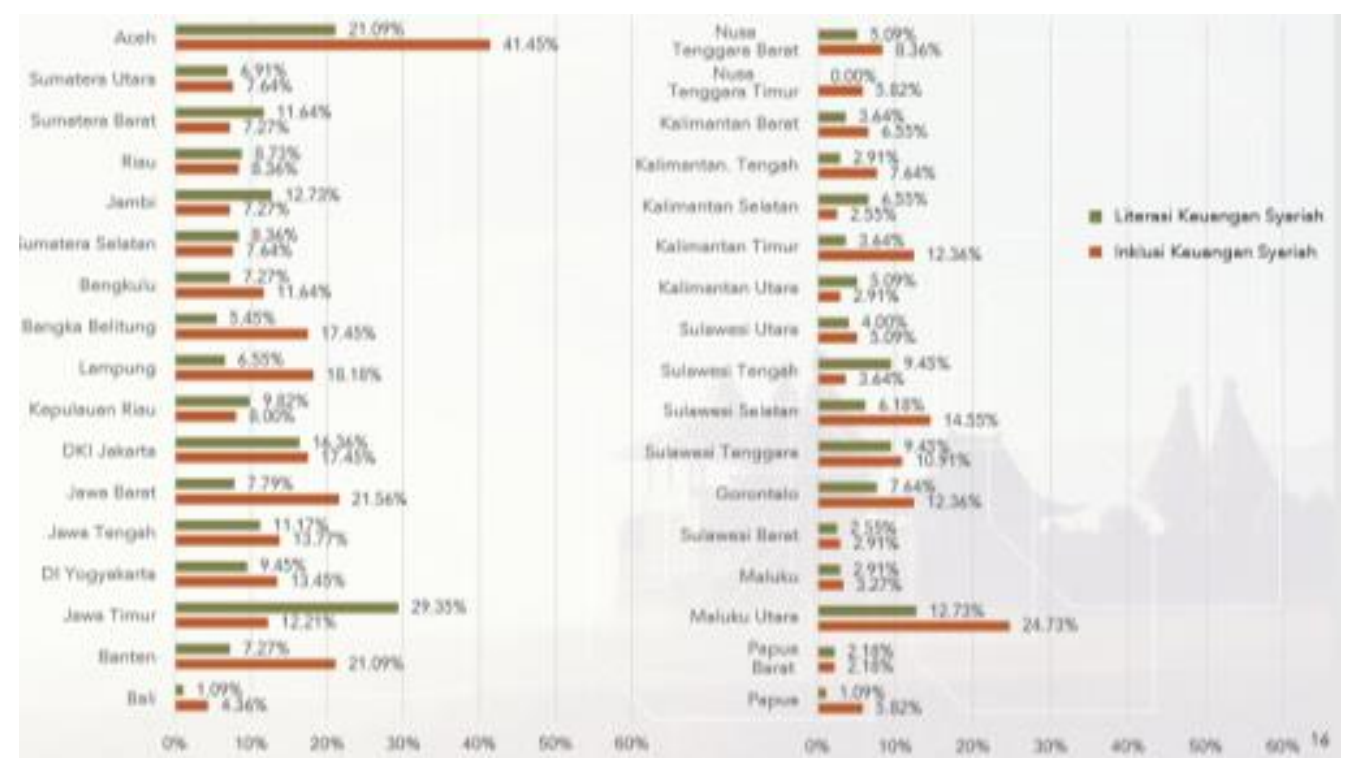

Source : Financial Services Authority(OJK)

Based on these data, the Papua region ranks lowest after Bali in terms of understanding literacy and Islamic finance. The Papua region at the eastern end of the archipelago is an area endowed with various potential riches of abundant natural resources. Whether it's on land or at sea, and is able to provide a decent life for its citizens. On land, lay agricultural land that is still very wide and fertile. In the area around the mountains there is also a wealth of minerals and minerals that are still not exploited, so they are still tangible in potential. While in the sea, contained the potential of marine wealth that provides a breath of life for its citizens. The development of population circulation in Papua is also increasing steadily increasing every year. This proves that the economic potential of this region will flourish if it is accompanied by the development of the character of its people. This fact should be used as an opportunity for the development of the Islamic economy. The huge potential of assets and the increasing population in Papua make this region worthy of attention and further development of financial literacy and financial inclusion in its Islamic capital market.

As a country consisting of various ethnic groups, Indonesia has a diversity of cultures that can be used as capital for economic development. The cultural diversity of 
the Indonesian people should not be a barrier to economic development. Cultural diversity can be converted into resources that support economic development. Culture as an economic resource is culture as an asset, which means culture as a container or a means of economic development. Social values and norms are tools for delivery or outreach, which then form the basis of mechanisms in economic development programs. (SUNARTI 2007)

The success of economic development is determined by the transformation of traditional culture into modern culture. Cultural transformation is a dynamic process in which culture which becomes a way of life changes and adapts according to the times. But cultural transformation is not an adoption of culture that absorbs it completely and leaves the old culture away, but adjusts cultural values to its social life. Cultural transformation that is in line with the stages of economic growth will create a balance so that clash or community disputes can be minimized or even avoided.(SUNARTI 2007)

Based on the explanation above, we need a concept and approach to increase the investment-conscious community in terms of understanding sharia capital market literacy in the form of a "Noken Literacy" program which is a value of local wisdom and is able to be an alternative solution to increase the financial literacy of the Papuan people. The problems presented above, can be overcome by the existence of a system approach to the field by civil society, students, and students who are members of a love literacy community that is interconnected with the Financial Services Authority and mutual support between one party and another, so that they are able produce quality people who are aware of the importance of investing.

\section{LITERATURE VIEW}

\section{a. Symbol Theory}

To explain a culture, symbol theories are needed, where symbols form culture. In this research several symbol theories are used as follows. Clifford Geertz (22: 1992), says that wherever and wherever there may be systems of symbols "in their own terms", G.H. Mead and other experts in Clifford Geertz (56: 1992), said that most of the symbols are words, but also signs, paintings, musical sounds, mechanical equipment such as clocks, or natural object.(Geertz 1992)

Almost all regions in Indonesia that have traditional traditions have undergone cultural transformation, where local cultures have undergone a process of diffusion with cultures from outside that came later. Joseph S. Roucek and Roland L. Warren (23: 1984) say Diffusion is the spread of cultural characteristics or complex characteristics of a society to other communities. This is how a society acquires new qualities. When two 
communities meet each other then diffusion occurs ". Further said if a culture borrows a new trait from another culture, it is usually changed to suit the practice and belief of the time ".(Roucek, Joseph S 1984)

Max Weber in Bryan S. Turner (649: 2010) says approaching culture is related to the ways culture places goals and actions arranged not only through interests, but also through norms. Anthony Giddens (282: 2010), explains in tribal societies or small oral cultures, the dominant structural principle applies along the axis that connects tradition with kinship ". Thus it can be said that local culture will be able to change if there is acceptance from community groups about new cultural elements that enter the middle of these community groups. But these changes still have local cultural characteristics that can not be lost as a whole, it's just that culture that comes to color the existing local culture so that it has characteristics that have experienced a blend of local culture with the culture that came later. (Turner 2012)

In line with the foregoing, Irwan Abdullah (261: 2002) also stated that the transformation of a society must contain three agendas, namely analytical transformation, historical transformation and practical transformation (Abdullah 2002) .This transformation process in its development resulted in the process of social change. The process of social change consists of three stages, namely: (1) invention which is the process by which new ideas are created and developed, (2) diffusion, is the process by which new ideas are communicated to the social system, and (3) Consequences namely changes that occur in the social system as a result of the adoption or rejection of innovation. Furthermore it is said that the fundamental change in the nature of groups and in the operation of the characteristics of a culture, is a new social cultural context $(16 ; 2010)$.

So, the interpretation of culture is basically an interpretation of symbols. From various theories about symbols, it can be said that each object, action, event, nature or relationship that can act as a vehicle for a conception, and a conception which is a symbol in the form of words, ornaments, songs, rhymes, poems, equipment and so on to form a culture so that it has the characteristics of a culture that is commonly used in various forms of rituals that distinguish one culture from another. In this case noken is a symbol of Papuan culture which is a means of effective communication between people.

\section{b. Theory of Effectiveness}


Soewarno Handayaningrat (1995: 16), said Effectiveness is a measurement in the sense of achieving a predetermined goal or goal ". Further explained by Soewarno Handayaningrat by relying on Emerson's thought above, he said the effectiveness of something has the meaning of achieving goals and objectives in accordance with a predetermined plan (Handayaningrat 1983). Conversely, if a target and goal are not achieved in accordance with the existing plan, then it is not effective ". Soewano Handayaningrat (1995: 16). Further said by Peter Drucker in Kisdarto (2002: 139), states that: effectiveness means the extent to which we achieve our goals and our efficiency mixes resources carefully. Opinions of the experts above can be explained, that effectiveness is an effort to achieve the desired goals (in accordance with expectations) aimed at many people and can be felt by the target group, namely the community.

Effectiveness comes from the effective word which means understanding the achievement of success in achieving the stated goals. Effectiveness is always related to the relationship between expected results and the results actually achieved. Effectiveness can be seen from various points of view (view point) and can be assessed in various ways and has a close relationship with efficiency. From the various opinions above, that if the achievement of the objectives of the organization is greater, the greater the effectiveness. This means, that the notion of effectiveness that is concerned is solely the desired outcome or goal, and effectiveness is more focused on the effect or influence. In this case, noken is a cultural symbol that is considered to be able to realize the effectiveness of public communication

\section{Research Methods}

\subsection{Research Types and Data Sources}

Research conducted included in the type of qualitative descriptive research, namely the analysis model that gives an idea of how the logic of data analysis (Arikunto 2009). The use of logical thinking uses the assumption of inter subjectivity, while the qualitative research verbs used are social phenomenology. Thus it can be explained that this research focuses on subjective meanings and experiences which aim to explain how objects and experiences are created in full meaning and are communicated in everyday life. In this paper the researcher places the theory at the beginning of the writing to be used as a guide or guide the author in developing the writing.

Data sources used in this study are primary and secondary data. Primary data is data directly collected by researchers from their first source by obtaining informants or subjects to be studied, namely the person in charge of the literacy program and the people who are targeted by the literacy program. Secondary data is data arranged in the form of documents or books, journals, scientific magazines obtained from the center 
of library studies related to the object under study. According to Kartini Kartono (27: 1990), said library research is a way to collect data and information with the help of various materials contained in the library room

Thus, the authors try to obtain data or secondary information by studying a number of notes, books, papers or other documents that are considered to have relevance to the problem under study. But in this study also conducted field research. This research took place at the research location (Research field). According to Taliziduhu Ndraha (115: 1993), field research is "research conducted in the field or research location, where events or symptoms that are the object of field research or are locations where primary data sources can be found". In this study, researchers went directly to the location of the study when the activities of the Noken literacy took place by literacy youths in traditional markets in Jayapura, so that the authors poured out all that was seen, what was understood, what was known, and what is heard, so that it can be concluded into writing (Ndraha 1993).

Several methods are used to obtain field data, namely by conducting passive participatory observation. In this passive participatory observation activity, the writer tries to carry out the activity of loading attention to an object with all five senses about certain symptoms by observing directly so that the researcher knows directly the object under study. In this case the researcher came at the location of the traditional market which is the place where the Noken literacy program took place and the researcher participated in the activities and made direct observations. In addition, in-depth interviews are also conducted, the depth of interviews conducted by the author is a dialogue or interview to obtain data that will be examined obtained from informants or informants, more freely, to get more open problems, by conducting unstructured interviews using assistance recording tools, notes, in collecting data.

\subsection{Research Types and Data Sources}

To be easy to understand from the results of this study, we need an analysis that is able to realize in a paper about the various findings in the research field. Lexy, said that data analysis is the process of systematically searching and compiling data obtained from interviews, field notes, other materials, so that they can be easily understood, and their findings can be shared with others (Moleong 2009). The data analysis technique used in this study is to use the Miles and Huberman model analysis technique (18: 1992), which analyzes data by dividing into three parts, namely: first by performing data reduction, namely summarizing data, selecting things the main thing, focus on the things that are important, and get rid of things that are not needed; second, conducting data display (data presentation), namely making a brief description, charts, relationships between 
categories and the like; and the third is conducting Conclusion Drawing / verification, namely drawing conclusions and verification (Miles and Huberman 1992) .

\section{RESULT AND DISCUSSION}

\subsection{Noken Literasi sebagai Program Bernilai Local Wisdom}

The land of Papua has beautiful and rich nature, and so do the ethnic groups. Quoting from a book entitled "Ethnic Maps in the Land of Papua" published by the Papua Provincial Culture Office in 2008 there were 248 ethnic groups inhabiting the land of Papua. With its diversity there is one interesting thing from the many cultures in Papua, namely objects called "noken". Titus Pekei is an ecologist and cultural observer in Papua who delivers noken so that it is recognized as one of the world's intangible cultural heritage by UNESCO on 4 December 2012. Melinjo wood fiber (Gnetum gnemon) is one of the plant species that can be used to make noken. "Noken is the mother who raised us. "Noken is us, we are noken", that is the sentence of Titus Pekei, the initiator of noken as Papua's cultural heritage.(Dinas Kebudayaan Provinsi Papua 2011)

Noken is a container resembling a bag (but not a bag) made from natural materials in the form of wood fibers or leaves (currently there are also those from yarn). The function of noken varies from loading family assets, garden produce, daily necessities, to holding a baby. To make noken, the main material must be cleaned, twisted, knitted or woven to form a pattern and a harmonious bond with each other. Making noken requires perseverance and patience. When the bonding of a noken is formed, the straps will support each other so that the noken becomes tough when loading a large volume of luggage.(Atmosoeprapto 2002)

Noken has a broad philosophy. Another philosophy embodied in a noken is the symbol of openness of the Papuan people. One of the speakers said that the noken which has a large inter-cavity form said that it was a symbol of openness. Open to the outside world and able to be friendly with every newcomer. Not surprisingly, the culture of local wisdom is included in the UNESCO cultural heritage. Local wisdom or local wisdom is the noble values handed down from the ancestors to the next generation who live and develop in the community. This means that if a local wisdom does not provide any benefits to the environment, it will undoubtedly be left by the community.

Noken as a value of wisdom should be preserved. One example of its preservation is to hold a program of activities that uses noken as a communication tool. The noken literacy program is a community of love literacy programs in Papua that was initiated by the Papuan Writing School with BP PAUD and the Papuan Public Health Council. This program arises because of the literacy activists' concerns about the low literacy of the Papuan financial conscious people who tend to spend money in a short period of time 
and have never had good financial planning. So this program is considered important to continue to be developed in raising the cultural image as well as the financial literacy of the Papuan people.

\subsection{Implications of Development of Noken Literacy on Increasing Financial Literacy}

Based on the index data of sharia financial literacy levels which are still low in Papua, it is fitting for an intensified financial literacy improvement program for its people. The literacy noken program is a community of love literacy programs, the Papuan Writing School together with BP PAUD and the Papuan Public Health Council. This program has the aim to build a Papuan society that loves literacy so that with a high level of literacy, Papuans will be more prosperous in life. Especially for the development of financial literacy, this needs to continue to be developed because the Papuan people who have a large income but tend to be considered spending their money in the short term and do not understand investment. In this situation the development of financial literacy becomes important to do.

Noken literacy is a program that initiates students who are deemed competent in understanding investment to approach traders in the shopping center in Jayapura to educate the public about the importance of understanding financial literacy. So that in the trade process, they are able to get capital not from loan sharks and their trade profits can be well invested. The Noken literacy program is initiated for students because they are considered capable of functioning as ambassadors for community renewal or "agents of social change".

Student groups and students with the nature and character are the younger generation who must prepare themselves to receive the national leadership relay from the previous generation in the future. They are not a traditionalist group but as "ambassadors of social renewal" in the sense of having to require continuous change toward progress based on truth values. Following is the framework of the financial literacy literacy program

Program Names

Organizer

Activist selection and training
: Literacy Noken "Financial Literacy", which is a field trip to the community carried out by literacy activists carrying noken bags containing financial reading books

: Literacy lovers community of Papuan Writing Schools with BP PAUD and Dikmas Papua.

: An online-based selection was carried out for students and students in the city of Jayapura so that participants who passed the selection would take a 


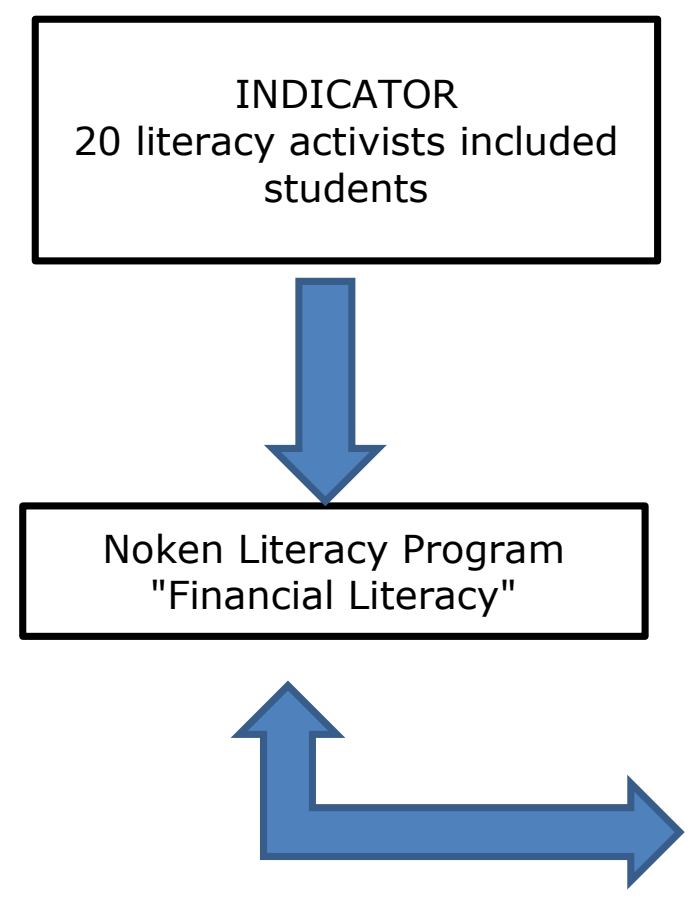

financial literacy training and be ready to go to the field. In the training session, literacy activists will receive material in the form of:

1. Material social approach to the target community.

2. Material Design Model for Literacy Education.

3. Financial Literacy Materials.

4. Ceremonial delivery of financial literacy books and noken bags to literacy enthusiast participants

Each activist will be targeted to go down the field eight times in one month and has a target of twenty people who are educated financial literacy. So if analogous to the target literacy program noken will be able to produce:

TARGET
1. 20 literacy activists go down the field 8
times in 1 month.
2. The target community of educated goals
is 20 people per literacy activist.
3. 20 activists will educate public financial
literacy with a total of 400 people within 1
month.
4. If this program is routinely and
consistently carried out within a one year
period, it will produce 4,800 people who will
recognize investment.
5. With the level of financial literacy that is
increasingly widespread, the potential of the
community to be aware of investment will be
higher so that it can help improve the
economy both macro and micro.

Figure : Parameters and targets of noken literacy programs

Target and programs goal

: 1. Increase public financial literacy according to criteria, namely those who have a business and are able to read and write well. 
2. Preserve the value of Papuan local wisdom by using noken as an effective means of communicating with the community.

3. Increased public interest in investing in safe government financial institutions.

4. Helping government programs in the context of national economic progress.

5. . Realizing students and students as agents of social change with the embodiment of love literacy to the community

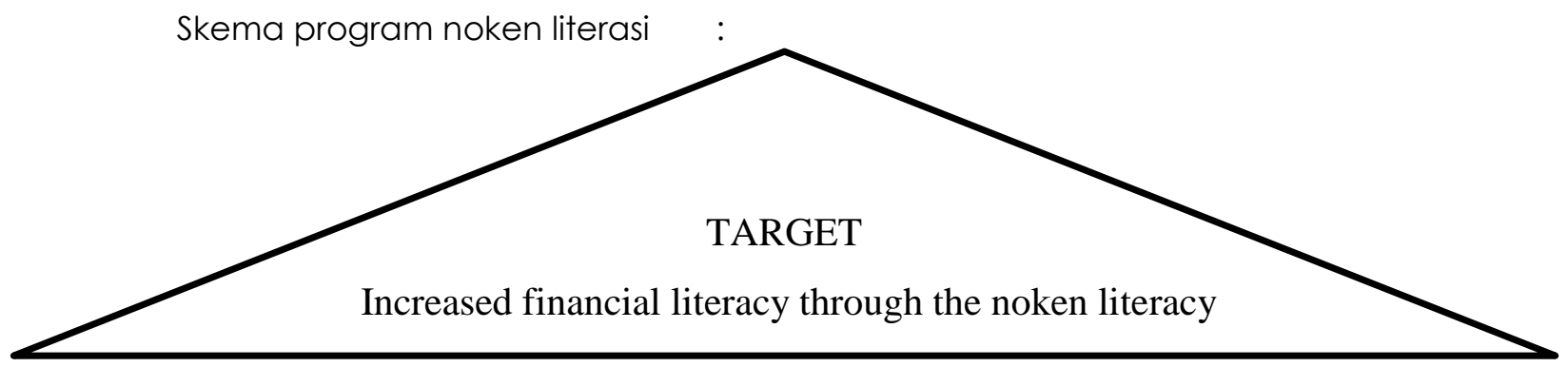

\begin{tabular}{|l|}
\multicolumn{1}{|c|}{ STEP 1 } \\
Literacy \\
activists were \\
selected from \\
Jayapura \\
students and \\
students. \\
Activists who \\
pass the \\
selection will be \\
trained in \\
financial literacy \\
material as well \\
as material on \\
effective \\
approaches to \\
the community. \\
\end{tabular}

\begin{tabular}{|l|}
\hline \multicolumn{1}{|c|}{ STEP 2 } \\
Literacy \\
activists who \\
have been \\
trained to go \\
down the field \\
by carrying a \\
standard \\
financial literacy \\
book in a noken \\
bag. assistance \\
to the \\
community for 8 \\
times in one \\
month according \\
to the location \\
determined \\
\end{tabular}

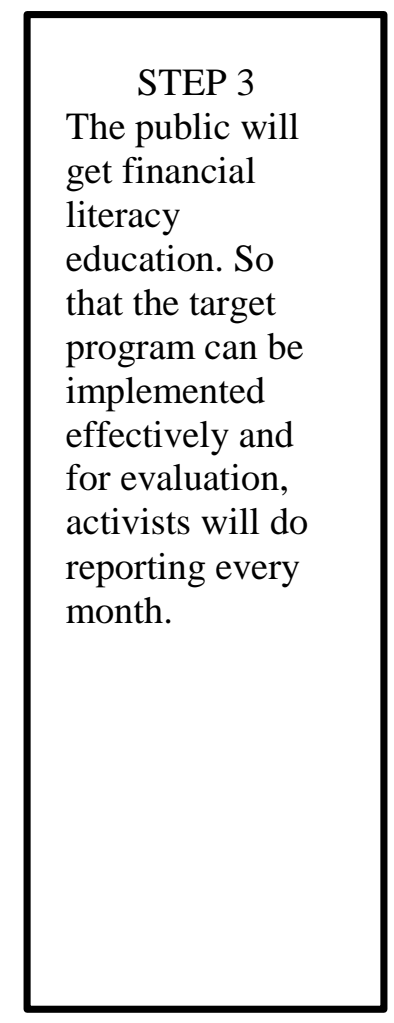

\begin{tabular}{|l|}
\hline \multicolumn{1}{|c|}{ STEP 4} \\
Within the \\
increase in \\
public financial \\
literacy, this will \\
help the \\
community \\
become aware \\
of investment. \\
So that this \\
program can \\
support national \\
economic \\
growth
\end{tabular}

Government as a supporter and partner of the program 
The noken literacy program applies 4 stages in its implementation to be realized the effectiveness and target of the program to expand the level of community literacy, the description is as follows:

a. Stage 1: Students and students as executors of activities in the field and community assistance are selected based on the conditions set by the organizer of the activity. The following criteria are students and students who are eligible to enter the program:

1.) High social mind

2.) Having a love of literacy

3.) know local Papuan wisdom in the form of noken

4.) has organizational experience

5.) Able to communicate well

6.) Writing an essay contributing to the world of literacy

a. Activists who meet these criteria will pass the selection program to subsequently attend financial literacy training noken which will be fostered directly by the Papuan Writing School, BP PAUD, and Papuan Public Health Organization. A total of 20 students will graduate at this stage. The material presented in the form of an approach to the community and material about financial literacy. In the training, each literate activist participant will get basic supporting books on financial literacy that have been prepared in such a way by the Papuan Writing School. Each literacy activist will get one Papuan noken bag as a tool used when going down the field.

b. Stage 2: Literacy activists take to the field by carrying noken containing books supporting financial literacy. Each literacy activity must go down to the field 8 times in a period of 1 month and it is targeted to have 20 fostered residents. To prove the number of residents that have been fostered, each literacy activist must collect data from the citizens with the following information:

1.) Name of fostered residents

2.) The last education of the target residents

3.) Fostered income per month

4.) Knowledge of fostered citizens about investment

5.) Knowledge of fostered citizens about banking

6.) Knowledge of fostered citizens about the capital market

7.) Availability of fostered citizens to invest in financial institutions

c. Stage 3: With a target of 20 fostered citizens within 1 month, as many as 20 literate activists are expected to be able to print 400 fostered citizens who are educated 
financial literacy. To improve the program, monthly evaluations are carried out by making reports by literacy activists to program organizers

d. Stage 4: With increasing public financial literacy, this will help the community become aware of investment. So that this program can support national economic growth.

\subsection{Opportunities and Challenges of Development of Noken Literacy}

The financial literacy literacy program is a program that is realized by the passion of the activists in the world of literacy. Literacy is an individual's ability to process and understand information when reading and writing. In other words, literacy is a set of skills and abilities in reading, writing, counting, and solving problems in their daily lives. The purpose of literacy is:

i. Helps increase public knowledge by reading a variety of useful information.

ii. Helps improve one's level of understanding in drawing conclusions from information read.

iii. Helps grow and develop good character in a person.

iv. Help improve the quality of one's time use so that it is more useful.

Seeing the purpose of literacy that is so good, of course people will get various benefits from it. One type of literacy that is currently being intensified by the government is financial literacy. According to the Financial Services Authority, financial literacy is a series of processes or activities to increase the knowledge, beliefs, and skills of consumers and the wider community so that they are able to manage finances well. With a good level of financial literacy, a person will be greatly helped to live more prosperously in financial terms. A good level of financial literacy is also beneficial for a country's economic system. There are 4 levels of financial literacy according to the Financial Services Authority, namely:

1.) Well Literate, that is the degree to which a person has knowledge and beliefs about financial service institutions. Not only that, they also recognize the features, benefits, risks, rights and obligations regarding financial products and services.

2.) Sufficient Literate, that is, someone has knowledge and beliefs about financial service institutions and financial products and services.

3.) Less Literate, that is, someone only has knowledge of financial service institutions and their products and services.

4.) Not Literate, that is, a person lacks knowledge and beliefs about financial service institutions. 
From these various aspects, the noken literacy program contributes to financial literacy in the land of Papua. Here are some opportunities for developing the Noken literacy program:

1.) The abundance of students and students in the city of Jayapura must function properly in carrying out the noken literacy program. Young people are believed to be full of high spirits. So it is very suitable if placed in a world of literacy that relies more on the burning spirit of enthusiasm. Another advantage of young people is that they are considered capable of scientific understanding, so that the target of these students is considered effective and a golden opportunity.

2.) The abundant number of students and students in Jayapura City must function properly in carrying out the noken literacy program. Young people are believed to be full of high spirits. So it is very suitable if placed in a world of literacy that relies more on the burning spirit of enthusiasm. Another advantage of young people is that they are considered capable of scientific understanding, so that the target of these students is considered effective and a golden opportunity

3.) The abundance of students and students in the city of Jayapura must function properly in carrying out the noken literacy program. Young people are believed to be full of high spirits. So it is very suitable if placed in a world of literacy that relies more on the burning spirit of enthusiasm. Another advantage of young people is that they are considered capable of scientific understanding, so that the target of these students is considered effective and a golden opportunity

4.) The large number of people who have businesses in traditional shopping centers that are targeted by this literacy program.

5.) Noken which is the uniqueness of this program is an attraction for the public in understanding literacy activists in explaining financial literacy materia

6.) This Program Can preserve the value of the noken image as the cultural heritage of the people of Papua.

To succeed this literacy program, of course there must be support from various parties,:

\begin{tabular}{|l|l|l|}
\hline Party & INDICATOR SUPPORT & OUTPUT \\
\hline School and College & $\begin{array}{l}|l| \\
\text { Directing students to } \\
\text { participate in various }\end{array}$ & Increase experience \\
activities outside of insight to & students and \\
& lectures that support soft & students in the \\
& skills and community & development of soft \\
\hline
\end{tabular}




\begin{tabular}{|c|c|c|}
\hline & $\begin{array}{l}\text { service. For example } \\
\text { following the literacy } \\
\text { program noken. }\end{array}$ & $\begin{array}{l}\text { skills that can be } \\
\text { explored through the } \\
\text { noken literacy } \\
\text { program. }\end{array}$ \\
\hline $\begin{array}{l}\text { Love Literacy Community } \\
\text { (Papuan Writing School) }\end{array}$ & $\begin{array}{l}\text { - Conducting literacy noken } \\
\text { programs or other literacy } \\
\text { activities regarding } \\
\text { financial knowledge on an } \\
\text { ongoing basis. }\end{array}$ & $\begin{array}{l}\text { - Development of } \\
\text { literacy and raising } \\
\text { the level of public } \\
\text { financial literacy }\end{array}$ \\
\hline Government & $\begin{array}{l}\text { - Supporting community } \\
\text { literacy improvement } \\
\text { activities in the form of } \\
\text { financial support and } \\
\text { supervision. }\end{array}$ & $\begin{array}{l}\text { - A good level of } \\
\text { financial literacy will } \\
\text { produce a good } \\
\text { economy } \\
\text { national } \\
\text { development }\end{array}$ \\
\hline $\begin{array}{ll}\text { Financial } & \text { Fervices } \\
\text { Authority (OJK) } & \end{array}$ & $\begin{array}{l}\text { - Support in terms of } \\
\text { providing material and } \\
\text { training during the literacy } \\
\text { program and initiating } \\
\text { more communities to go to } \\
\text { the community in terms of } \\
\text { increasing financial } \\
\text { literacy. }\end{array}$ & $\begin{array}{l}\text { - The level of public } \\
\text { financial literacy } \\
\text { index will increase } \\
\text { and people will be } \\
\text { more aware of } \\
\text { investment. }\end{array}$ \\
\hline
\end{tabular}

From the opportunities that have been described, the Noken literacy program also has various challenges to be faced namely:

1.) Lack of interest and love of students and students in the world of literacy.

2.) The lack of a literacy-loving community that would be moved to implement a literacy program like this noken literacy.

3.) Lack of support from the government as a party that plays a role in the supervision and support of funds.

4.) Implementation of literacy activist training that has not been touched by the Financial Services Authority as an effective material provider.

5.) Lack of synergy from related parties for the development of this literacy program. 


\section{CONCLUSIONS AND RECOMMENDATIONS}

Papua is an area whose natural resource potential has no doubt. This abundant natural wealth is certainly an opportunity for better economic development. But in fact, Papua is a province with the lowest level of literacy and Islamic financial inclusion after Bali. Ppaua's Islamic financial literacy index is only around $1.09 \%$, which means that of the 100 people surveyed, only 1 person understands the use of Islamic financial products. Even though in recent years Islamic financial assets in the East have continued to increase by $41.62 \%$ yoy. Seeing this is certainly an opportunity as well as a big challenge for the Financial Services Authority to improve the Islamic financial industry in Papua.

In terms of increasing financial literacy, a noken literacy program was initiated as an answer to the problem. Noken literacy is a local wisdom program implemented by a literacy community in the land of Papua. This program was initiated with the aim of increasing the understanding of people in Papua about financial literacy. The method of implementation is by conducting field trips and direct assistance to the people involved in the economic activities of the market center in the Jayapura area. What distinguishes this program from other programs is because of the uniqueness of the objects carried by literacy activists when they go down to the field, namely a noken bag. Noken is one type of typical Papuan bag that has many philosophies about the Papuan people. It is hoped that the approach to using this unique bag of Papua will make people interested in understanding about financial literacy carried out by literacy activists. (Sachari 2007)

Literacy activists in the Papuan Writing School are only a part of civil society who have demonstrated their competence to take part in society. Next is a joint task between the community, the government, and the Financial Services Authority both at the central and regional levels to support the financial literacy movement valued at local wisdom as initiated by the Papuan Writing School. The aim is not only to increase public financial literacy, but also to preserve the value of local wisdom as a powerful weapon in attracting interest and effective communication to local communities. The efforts of the noken literacy program are only small movements that are expected to become a snowball community based national financial literacy movement. That to start something big must start from the small things first.(Littlejohn 2014)

\section{REFERENCE}

[1]Abdullah, Irwan. 2002. "Tantangan Pembangunan Ekonomi Dan Transformasi Sosial: Suatu Pendekatan Budaya(The Challenges of Economic Development and Social Transformation: A Cultural Approach)." Jurnal Humaniora 14 (3): 260-70.

[2] Arikunto, Suharsimi. 2009. Prosedur Penelitian: Suatu Pendekatan Praktik. (Research 
Procedure: A Practical Approach.). Jakarta: PT. Rineka Cipta.

[3]Atmosoeprapto, Kisdarto. 2002. Menuju SDM Berdaya - Dengan Kepemimpinan Efektif

Dan Manajemen Efisien (Towards Empowered HR - With Effective Leadership and Efficient Management). Jakarta: PT.Elex Media Komputindo.

[4]Dinas Kebudayaan Provinsi Papua. 2011. Peta Suku Bangsa (Etnik) Di Tanah Papua, (Map of Ethnic Groups in the Land of Papua) Summer Institute of Linguistic (SIL). Dewan Adat Papua: CV EYGA.

[5]Financial Service Authority (OJK). 2019. "Survei Nasional Literasi Dan Inklusi Keuangan 2018 (National Literacy and Financial Inclusion Survey 2018)." Jakarta.

[6]Geertz, Clifford. 1992. Tafsir Kebudayaan (Cultural Interpretation). Yogyakarta: Kanisius.

[7] Handayaningrat, Soewarno. 1983. Pengantar Studi llmu Administrasi Dan Managemen (Introduction to the Study of Administration and Management). Gunung Agung.

[8]Littlejohn, Stephen W. 2014. Teori Komunikasi (Communication Theory). Jakarta: Salemba Humanika.

[9]Miles, Matthew B, and A Michael Huberman. 1992. "Analisis Data Kualitatif (Qualitative Data Analysis)." Jakarta: UI press.

[10]Moleong, Lexy J. 2009. Metodologi Penelitian Kualitatif /Qualitative Research Methodology). Metodologi Penelitian Kualitatif (Edisi Revisi). Bandung: PT Remaja Rosdakarya.

[11]Ndraha, Taliziduhu. 1993. Research, Teori Methodologi Administrasi (Research, Administrative Methodology Theory). Jakarta: Bina Aksara.

[12]Roucek, Joseph S, and Warren L. Roland. 1984. Pengantar Sosiologi(Introduction to Sociology). Jakarta: Bina Aksara.

[13]Sachari, Agus. 2007. Budaya Visual Indonesia: Membaca Makna Perkembangan Gaya Visual Karya Desain Di Indonesia Abad Ke-20(Indonesian Visual Culture: Reading the Meaning of the Development of Visual Styles of Design Works in 20th Century Indonesia). Erlangga.

[14]SUNARTI, S R I. 2007. "Sosiologi (Sociology)." Sukoharjo: Graha Multi Grafiko.

[15]Turner, Bryan S. 2012. "Teori Sosial Dari Klasik Sampai Postmodern (Social Theory from Classical to Postmodern)." Yogyakarta: Pustaka Pelajar. 

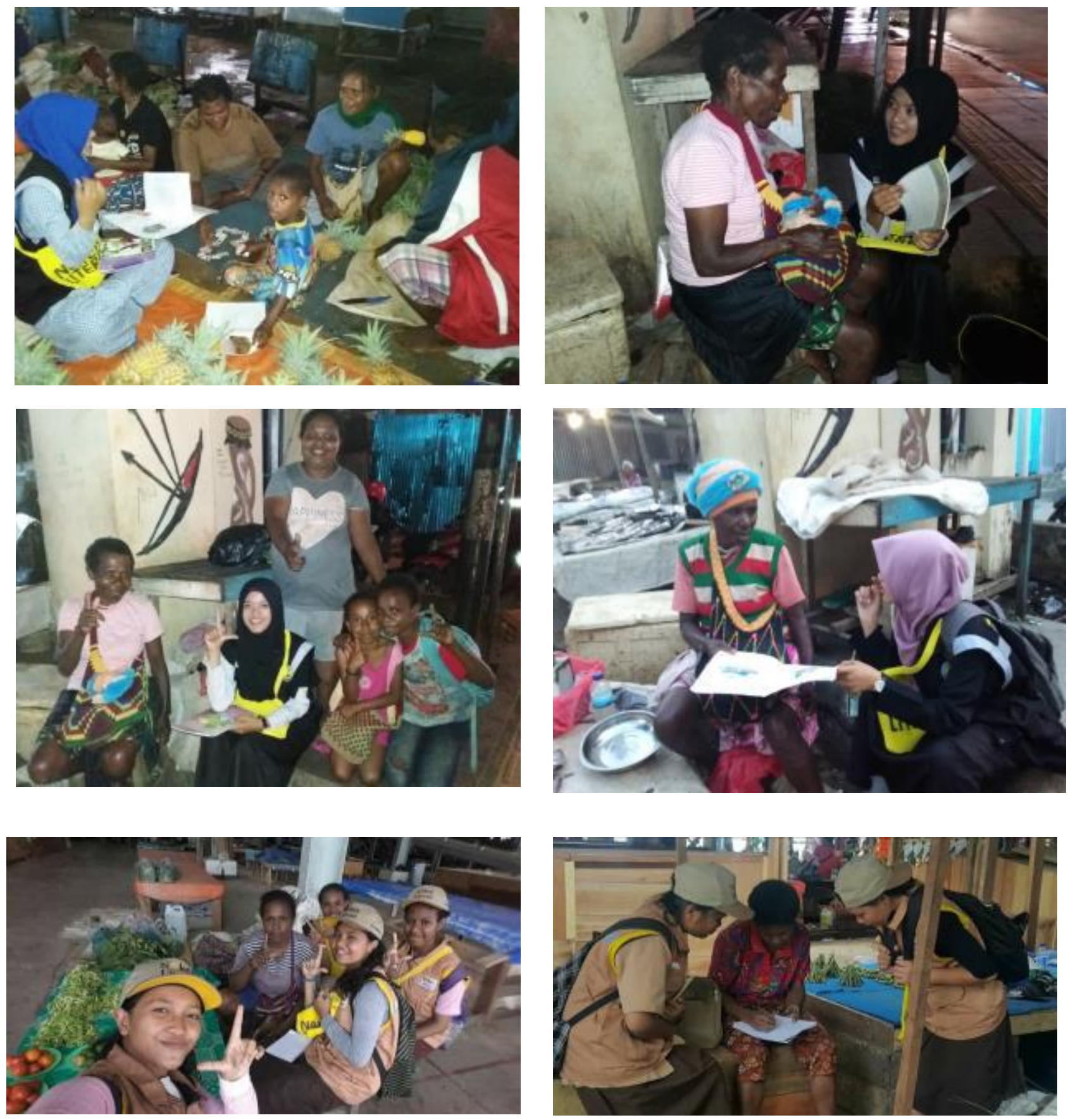